\title{
Use of social networks in emerging adults: The role of irrational beliefs
}

\author{
Irena B. Stojkovića , Tatjana D. Vukosavljević-Gvozden ${ }^{\mathrm{b}}$ \\ ${ }^{a}$ University of Belgrade - Faculty of Special Education and Rehabilitation, Belgrade, Serbia \\ ${ }^{b}$ University of Belgrade - Faculty of Philosophy, Belgrade, Serbia
}

Introduction. The use of online social networks has become widespread among the young. Although it may have beneficial effects, it has been established that some people develop problematic or excessive use of social networks which may negatively impact their psychosocial functioning. Objective. The aim of the present study was to investigate social networks use among emerging adults and to explore whether irrational and rational beliefs as conceptualized within the Rational-Emotive \& Cognitive-Behavior Therapy (RE\&CBT) framework predict problematic social networks use. Following RE\&CBT framework, we hypothesized that irrational beliefs are positively, and rational beliefs negatively related to problematic social networks use. Methods. The sample included 210 emerging adults (age range $18-26, M=21.08, S D=2.02$ ), $59.0 \%$ females. Serbian version of the General Attitude and Belief Scale (SGABS) was used for the assessment of irrational and rational beliefs. Serbian version of Internet Addiction Test was adapted for the assessment of problematic social networks use. Results. The results supported the hypothesis that irrational beliefs are positively related to problematic social networks use. When controlling for intercorrelations between beliefs, demands for love and approval from others stood out as a single significant predictor of problematic social networks use. Rational beliefs were unrelated to problematic social networks use, thus not supporting the hypothesis. Conclusion. The results suggest that RE\&CBT approach, which has been proven to be efficacious in prevention of various problems of psychosocial functioning may also provide framework for supporting young people to use social networks in a constructive way.

Keywords: problematic social networks use, irrational beliefs, rational beliefs, Rational-Emotive \& Cognitive-Behavioral approach, emerging adults

\footnotetext{
*Correspondence: Irena Stojković, irenas@fasper.bg.ac.rs
} 


\section{Introduction}

\section{The use of social networks}

Internet-based communications have developed intensely during the last decades and have penetrated various spheres of everyday life of the young. Internet is used for various purposes: getting information, shopping, entertainment, education, etc. Social network sites (e.g. Instagram, Twitter, Snapchat), as a domain of Internet communication, have been vastly accepted among persons of different ages, but especially among the young. Social network sites are "web-based services that allow individuals to (1) construct a public or semi-public profile within a bounded system, (2) articulate a list of other users with whom they share a connection, and (3) view and traverse their list of connections and those made by others within the system." (Boyd \& Ellison, 2008, p. 211). There are studies which show that social networking has become the most popular online activity, especially among young people (e.g., Griffiths \& Szabo, 2014).

Social networks may provide a broad avenue for the development of young people and may positively contribute to that development. It was shown that social networks are used for self-initiated enterprise and self-directed learning (Tan \& Kim, 2019). Furthermore, they enable formation and maintenance of the bridging and the bonding social capital (Ellison et al., 2007). The former refers to weak ties among members of large and diffuse relationship networks, and the latter to close relationships between friends and family members. Other studies also found an association between social networks use and friendship closeness among adolescents (Antheunis et al., 2016; Rousseau et al., 2019). Given the importance of friendships for emotional adjustment of young people (Brown $\&$ Klute 2003), it may be expected that the use of social networks positively contributes to well-being. Indeed, it was shown that social capital and feelings of connectedness provided by social networks contribute to subjective wellbeing. However, this seems to hold only for active users of social network sites, while passive use is related to lower subjective well-being because of social comparison and envy (Verduyn et al., 2017). Social network use may also contribute positively to identity development of typical adolescents (e.g., Davis, 2013), as well as adolescents who belong to minority groups such as sexual minority groups (Bates et al., 2020).

Although there are findings which support beneficial effects of social networks for the development of the young, negative effects were also established. Allen et al. (2014) point out that research evidence on the relationship between use of social networks and adolescents' sense of belonging, psychosocial wellbeing and identity development is mixed. A systematic review showed that the use of social networks is related to depression and anxiety although the effects are small (Piteo \& Ward, 2020). Another review study suggests that 
there is a negative relationship of a small size between social media use and psychological well-being (Orben, 2020). Shah et al. (2020) point to research that shows negative effects of social networks use in terms of low self-esteem and body satisfaction, higher risk of cyber-bullying and risky sexual behavior.

\section{Problematic social networks use}

Various factors may explain equivocal findings regarding social networks use and psychosocial functioning of the young, such as the type and structure of the networks a person belongs to, and the type of activities she/he undertakes. One prominent aspect of social networks use, which is related to negative effects, is excessive use. Excessive or problematic use of social networks is considered to be a form of behavioral addiction. Behavioral addictions are characterized by a diminished control, which is a core defining feature of substanceuse addictions, but over behaviors not related to ingestion of a psychoactive substance (Grant et al., 2010). Although there is a debate whether the concept of behavioral addictions is warranted (e.g. Billieux et al., 2015; Petry et al., 2018) research on behavioral addictions expands.

Internet addiction as a form of behavioral addiction has been extensively investigated since Young introduced the concept in 1990's (Young, 1997). However, it has been suggested that the notion of Internet addiction is heterogeneous and that, instead, specific forms of behaviors, which may become excessive through the use of Internet as a medium, should be investigated (e.g., Starcevic \& Aboujaoude, 2017). One of such behaviors is social networks use (Müller et al., 2016).

Various terms are used to denote excessive social networks use, such as compulsive social networks use, social networks addiction, and problematic social networks use. In their review study, Anfreassen and Pallesen (2014) use the term social networks sites addiction and define it as being overly concerned about these networks, and being driven to devote time and effort to these networks to a degree that impairs an individual's social, academic, and professional activities, as well as psychological health and well-being.

Studies on representative national samples showed that about $4.5 \%$ percent of Hungarian adolescents (Bányai et al., 2017) and about $2.9 \%$ of adults in Belgium (De Cock et al., 2014) suffer from problematic social networks use. Recently, the concept of Internet communication disorder has begun to be investigated, referring to dysfunctional use of social networks and messaging applications (e.g., WhatsApp) (Wegmann et al., 2018). However, majority of studies have concentrated on social networks use. Also, there is a lack of empirical evidence on whether the use of social networks and messaging applications may be regarded as a unitary phenomenon.

Problematic or excessive social networks use is related to various negative aspects of psychosocial functioning in adolescents and young adults: lower 
self-esteem (Kalpidou et al., 2011), lower academic achievement (Kirschner $\&$ Karpinski, 2010), and disconnection or isolation from peers (Barker, 2009). Numerous studies point to the association between problematic social networks use and psychopathological tendencies, especially anxiety and depression (Oberst et al., 2017; Pontes, 2017; Pontes et al., 2018; Sampasa-Kanyinga \& Lewis 2015). It is also related to other addictions such as Internet addiction and problem drinking (Hormes et al., 2014). Longitudinal studies suggest that the relationship between social networks use and psychopathological tendencies might be bidirectional, with psychopathology predicting an increase in social network use (Gámez-Guadix, 2014) and vice versa (Chen et al., 2020; GámezGuadix, 2014).

Given the expansion of social networks use and their relevance for psychosocial functioning, an important question is what predisposes persons for problematic social networks use. Przybylski et al. (2013) introduced the concept of the Fear of Missing Out (FoMO), defined as "a pervasive apprehension that others might be having rewarding experiences from which one is absent" (Przybylski et al., 2013, p. 1841). Further studies have confirmed that FoMO is related to problematic social networks use (e.g., Beyens et al., 2016; Oberst et al., 2017; Wegmann et al., 2017), and showed it to be a mediator of the relationship between psychopathological tendencies and problematic social networks use (Wegmann et al., 2017). Beyens et al. (2016) reported that FoMO mediates the relationship between psychological needs for belonging and popularity and stress related to Facebook use.

Recently, the Interaction of Person-Affect-Cognition-Execution(I-PACE) model of the development and maintenance of specific Internet-related and other addictive behaviors has been developed (Brand et al., 2016, 2019). The model explains development and maintenance of addictive behaviors through interaction of personal core characteristics as predispositions, affective and cognitive responses to specific stimuli, and executive functions. In accordance with the model, the role of narcissism, reward sensitivity and impulsivity in problematic social networks use was elucidated (Lyvers et al., 2019). Further, it was shown that impulsivity contributes to problematic social networks use especially when it is accompanied by deficiencies in executive functions and specific inhibitory control (Wegmann et al., 2020). Other personal core characteristics, besides narcissism, impulsivity and reward sensitivity, which might contribute to problematic social networks use, are worth investigating. Rational and irrational beliefs, as conceptualized in rational emotive and cognitive behavioral theoretical framework may be relevant in this regard. 


\section{Rational Emotive and Cognitive Behavior Therapy (RE\&CBT) theoretical framework}

Given the expansion of social networks use and their relevance for psychosocial functioning, an important question is what predisposes persons for problematic social networks use. Theoretical framework of RE\&CBT posits that cognitions in form of beliefs play an important role in emotional and behavioral functioning of individuals (DiGiuseppe et al., 2014; Ellis \& Dryden, 1997).

RE\&CBT distinguishes between rational and irrational beliefs. Rational beliefs are preferential evaluative cognitions, whereas irrational beliefs are absolutistic evaluations in form of "musts" or "shoulds" (Ellis \& Dryden, 1997). Rational beliefs are flexible or non-extreme, consistent with reality and logical. Contrary to that, irrational beliefs are rigid or extreme, inconsistent with reality, and illogical. RE\&CBT theory posits four types of rational beliefs: non-dogmatic preferences, non-awfulizing beliefs, high frustration tolerance beliefs, and selfother-, and life-acceptance beliefs. These beliefs lead to functional emotions and adaptive behaviors. Opposed to them are four types of irrational beliefs: absolutistic demands, awfulizing beliefs, low frustration tolerance beliefs, and self-, other-, and life-depreciation beliefs. These beliefs lead to dysfunctional emotions and behaviors.

There is empirical evidence that irrational beliefs are related to various forms of psychosocial malfunctioning and self-defeating behaviors (Szentagotai \& Jones, 2010), as well as to emotional disorders and symptoms (David et al., 2010). On the other hand, research on the relationship between rational beliefs and emotional and behavioral outcomes is less consistent and suffers from methodological flaws (David et al., 2010). The role of irrational beliefs in Internet-related addictions was established in a previous study which showed a relationship between irrational beliefs and Internet gaming addiction among high school and university students (Vukosavljevic-Gvozden et al., 2015). Specifically, factors of irrational beliefs - other-downing, self-downing, need for achievement, need for approval, demands for fairness, and need for comfort correlated with internet gaming addiction, while rational beliefs were uncorrelated with internet gaming disorder.

\section{The present study}

The aims of the study are the following: 1) to investigate social networks use during emerging adulthood, i.e., to investigate the distribution of study participants within particular categories of normal and problematic social networks use; and 2) to explore whether irrational and rational beliefs as conceptualized within the RE\&CBT framework predict social networks use. In accordance with I-PACE model (Brand et al., 2016, 2019), these beliefs may be regarded as core personal characteristics which may predispose individuals for problematic social networks use. 
Emerging adulthood is a period of life spanning from the end of adolescence to the undertaking of young adults' decisions regarding love, work, and worldviews (Arnett, 2000). It is a period of identity exploration and experimentation and persons in this developmental period are especially prone to substance and behavioral addictions (Sussman \& Arnett, 2014). Elucidating the relationship between irrational/rational beliefs and problematic social networks may contribute to scientific understanding and provide directions for practice of supporting the functional, non-problematic use of social networks by the young.

Based on the postulates of RE\&CBT theory, that irrational beliefs are conducive to dysfunctional emotions and behavior, whereas rational beliefs lead to functional emotions and adaptive behavior (e.g. Ellis, 1994), and on empirical evidence that endorsement of irrational beliefs is related to various dysfunctional behaviors (Szentagotai \& Jones, 2010) and psychopathological tendencies (Browne et al., 2010), and on empirical evidence, albeit weaker, that rational beliefs contribute to emotional well-being and adequate psychosocial functioning (Caserta et al., 2010; Oltean \& David, 2018), we hypothesize the following:

Hypothesis 1: Irrational beliefs are positively related to problematic social networks use, and the group of persons who display problematic social networks use have higher scores of irrational beliefs compared to the group with non-problematic social networks use.

Hypothesis 2: Rational beliefs are negatively related to problematic social networks use, and the group of persons who display problematic social networks use have lower scores of rational beliefs compared to the group with non-problematic social networks use.

\section{Methods}

\section{Sample and procedure}

The convenience sample included 210 emerging adults (age range from 18 to 26 years, $M=21.08, S D=2.02$ ), $59.0 \%$ females, who study at the Faculty of Special Education and Rehabilitation, University of Belgrade, or were recruited through personal contacts of students of that faculty. The questionnaires were administered online. Participants were informed on the purpose of study in written form prior to responding to questionnaires. 


\section{Variables and measures}

\section{Irrational and rational beliefs}

Serbian Version of the General Attitude and Belief Scale (SGABS; Marić, 2002, 2003), an adaptation of the General Attitude and Belief Scale (GABS; Bernard, 1998; DiGiuseppe et al. 1988), was used for the assessment of rational and irrational beliefs. The scale consists of 37 items, 29 of them reflecting irrational and 8 reflecting rational beliefs. Participants indicate the extent to which they agree with each statement on a 5-point Likert scale ranging from 1 - strongly disagree to 5 - strongly agree. We applied principal components analysis with promax rotation on the items expressing irrational beliefs. The analysis using Cattell's scree plot yielded four factors of irrational beliefs: Demands for other persons' correctness and other-depreciation, Perfectionist demands toward oneself, Demands for love and approval from others, and Self-depreciation. Mean scores for each type of irrational beliefs were obtained by averaging the items with highest pattern coefficients on the corresponding factor. Mean score of rational beliefs was obtained by averaging the items expressing rational beliefs. The reliability of irrational beliefs' scales was good with Cronbach's alphas ranging from .82 to .87. The reliability of rational beliefs' scale was below acceptable $(\alpha=.60)$.

\section{Problematic social networks use}

Serbian version of Internet Addiction Test (Popović-Ćitić \& Marković, 2013) was adapted for the assessment of problematic social networks use by replacing the term "internet" with the term "social networks", following the procedure by Musetti et al. (2021). Further, as the Serbian version is constructed for the use with schoolaged children and adolescents, in order to make it suitable for emerging adults, we slightly changed some items, for example by adding work and faculty obligations to formulations referring to school assignments. The scale consists of 20 items. The items refer to problems in controlling the time spent on social networks, interpersonal conflicts due to social networks use, neglect of duties, disturbed sleep, preoccupation with social networks while offline, using social networks to escape from disturbing feelings. For each item, respondents are asked to select the response which best describes them on a 6 -point Likert scale ranging from 0 - never to 5 - always. The reliability of the scale established in this study was high $(\alpha=.90)$. The total scores may range from 0 to 100. Young (2011) made the following classification of total scores: normal use (0-30), mild problematic use (31-49); moderate problematic use (50-79) and severe problematic use (80-100). Normal use means that the person can control the use of social networks so that her obligations and interpersonal relations are not disturbed, mild and moderate problematic use refers to frequent problems, and severe problematic use refers to serious problems related to social networks use (PopovićĆitić \& Marković, 2015). 


\section{Results}

\section{Descriptive statistics for study variables}

Descriptive statistics for study variables are presented in Table 1.

\section{Table 1}

Descriptive statistics for study variables

\begin{tabular}{lccccc}
\hline Variable & Min & Max & $M$ & SD & $\begin{array}{c}\text { Shapiro- } \\
\text { Wilk's }\end{array}$ \\
\hline Problematic social networks use & 1.00 & 94.00 & 27.54 & 14.29 & $.96^{*}$ \\
$\begin{array}{l}\text { Demands for other persons' correctness } \\
\text { and other-depreciation }\end{array}$ & 1.00 & 5.00 & 2.10 & 0.85 & $.91^{*}$ \\
Perfectionist demands toward oneself & 1.36 & 4.73 & 2.80 & 0.75 & $.98^{*}$ \\
Self-depreciation & 1.00 & 4.40 & 1.40 & 0.66 & $.65^{*}$ \\
$\begin{array}{l}\text { Demands for love and approval from } \\
\text { others }\end{array}$ & 1.00 & 5.00 & 2.85 & 1.06 & $.97^{*}$ \\
Rational beliefs & 2.00 & 5.00 & 4.08 & 0.56 & $.97^{*}$ \\
\hline Note. ${ }^{*} p<.01$ & & & & &
\end{tabular}

According to Shapiro Wilk's test, distributions of all study variables significantly deviated from normal distribution (Table 1). Thus, we used normalized scores based on Blom's formula in analyses of the relationship between study variables.

\section{Distribution of subjects in particular categories of problematic social networks use}

In accordance with the first aim of the study, to investigate the distribution of participants regarding social networks use, we classified subjects into particular categories of problematic social networks use based on cut-off points devised by Young (2011) for classification of Internet addiction according to Internet addiction test. The classification is presented in Table 2 .

\section{Table 2}

Distribution of subjects in particular categories of problematic social networks use

\begin{tabular}{lcc}
\hline Problematic social networks use category (score range) & $n$ & $\%$ \\
\hline Normal social networks use (0-30) & 130 & 61.9 \\
Mild problematic social networks use (31-49) & 64 & 30.5 \\
Moderate problematic social networks use (50-79) & 15 & 7.1 \\
Severe problematic social networks use (80-100) & 1 & 0.5 \\
Total & 210 & 100 \\
\hline
\end{tabular}


The further analyses were performed on the whole study sample. In accordance with the second aim of the study, and in order to test the hypotheses that irrational beliefs are positively, and rational beliefs negatively related to problematic social networks use, bivariate correlations were employed.

\section{Bivariate correlations between study variables}

Bivariate correlations between study variables are presented in Table 3 .

\section{Table 3}

Bivariate correlations between study variables (Pearson r)

\begin{tabular}{|c|c|c|c|c|c|c|}
\hline \multirow{2}{*}{\multicolumn{7}{|c|}{$\begin{array}{l}\text { Variable } \\
\text { 1. Problematic social networks use }\end{array}$}} \\
\hline & & & & & & \\
\hline $\begin{array}{l}\text { 2. Demands for other persons' } \\
\text { correctness and other-depreciation }\end{array}$ & $.23^{* * *}$ & & & & & \\
\hline 3. Perfectionist demands toward oneself & $.22^{* *}$ & $.47^{* * *}$ & & & & \\
\hline 4. Self-depreciation & $.22^{* *}$ & $.30^{* * *}$ & $.48^{* * *}$ & & & \\
\hline $\begin{array}{l}\text { 5. Demands for love and approval from } \\
\text { others }\end{array}$ & $.30^{* * *}$ & $.39^{* * *}$ & $.44^{* * *}$ & $.32^{* * *}$ & & \\
\hline 6. Rational beliefs & -.13 & $-.24^{* * *}$ & $-.34^{* * *}$ & $-.35^{* * *}$ & $-.29^{* * *}$ & \\
\hline
\end{tabular}

Note. ${ }^{* *} p<.01,{ }^{* * * *} p<.001$

Problematic social networks use is significantly positively related to all irrational beliefs, with Demands for love and approval from others showing moderate and other irrational beliefs low correlation with problematic social networks use. Problematic social networks use is unrelated to rational beliefs. All types of irrational beliefs are positively interrelated (correlations are of moderate size), while they show negative correlations (low to moderate) with rational beliefs.

\section{Multiple regression analysis with problematic social networks use as dependent variable and irrational and rational beliefs as predictors}

In order to investigate the relative contribution of different types of beliefs to social networks use, multiple regression was performed. The results of multiple regression analysis for prediction of problematic social networks use from irrational and rational beliefs are presented in Table 4 . The multiple regression model was statistically significant $(F(96,5)=5.40, p<.01)$. The predictors accounted for $12 \%$ of variance in Problematic social networks use. As shown in Table 4, Demands for love and approval from others is the only significant predictor of problematic social network use when taking into account the interrelationships between different types of beliefs $(\beta=.23, p<.01)$. 


\section{Table 4}

Results of multiple regression for predicting problematic social networks use from irrational and rational beliefs

\begin{tabular}{lccc}
\hline Variable & $B$ & $S E_{B}$ & $\beta$ \\
\hline $\begin{array}{l}\text { Demands for other persons' correctness and } \\
\text { other-depreciation }\end{array}$ & 0.11 & 0.08 & .10 \\
Perfectionist demands toward oneself & 0.03 & 0.09 & .03 \\
Self-depreciation & 0.12 & 0.09 & .10 \\
Demands for love and approval from others & 0.23 & 0.08 & $.23^{* *}$ \\
Rational beliefs & 0.02 & 0.08 & .02 \\
\hline
\end{tabular}

Note. ${ }^{* *} p<.01$

\section{Results of multivariate analysis of variance: differences in irrational and rational beliefs between subjects with problematic and non-problematic social networks use}

In accordance with the second aim of the study, and to test the hypotheses that the groups of participants with normal vs. problematic social networks use (aggregated mild, moderate and severe categories) differ in the level of irrational and rational beliefs a multivariate analysis of variance was performed. There was a statistically significant difference between the groups with normal vs. problematic social networks use on the combined variables of rational and irrational beliefs $(F(5,205)=3.12, p=.010$, Wilks' Lambda $=.93)$. The results for the types of beliefs considered separately are presented in Table 5.

\section{Table 5}

Results of multivariate analysis of variance: differences in irrational and rational beliefs between subjects with problematic and non-problematic social networks use

\begin{tabular}{|c|c|c|c|c|c|}
\hline \multirow[t]{2}{*}{ Variable } & \multicolumn{2}{|c|}{$\begin{array}{l}\text { Non-problematic } \\
\text { social network use }\end{array}$} & \multicolumn{2}{|c|}{$\begin{array}{l}\text { Problematic social } \\
\text { network use }\end{array}$} & \multirow[t]{2}{*}{$F(1,209)$} \\
\hline & $M$ & $S D$ & $M$ & $S D$ & \\
\hline $\begin{array}{l}\text { Demands for other persons' } \\
\text { correctness and other-depreciation }\end{array}$ & -0.18 & 0.96 & 0.31 & 0.93 & $12.72^{* * *}$ \\
\hline $\begin{array}{l}\text { Perfectionist demands toward } \\
\text { oneself }\end{array}$ & -0.13 & 0.96 & 0.27 & 0.94 & $8.34^{* *}$ \\
\hline Self-depreciation & -0.07 & 0.80 & 0.24 & 0.89 & $6.31^{*}$ \\
\hline $\begin{array}{l}\text { Demands for love and approval } \\
\text { from others }\end{array}$ & -0.14 & 0.96 & 0.23 & 0.97 & $7.49^{* *}$ \\
\hline Rational beliefs & 0.09 & 0.92 & -0.10 & 1.03 & 1.79 \\
\hline
\end{tabular}

Note. ${ }^{*} p<.05,{ }^{* *} p<.01,{ }^{* * *} p<.001$ 
Results in Table 5 show that subjects with problematic social networks use have significantly higher levels of all types of irrational beliefs compared to subjects with non-problematic social networks use, while differences in rational beliefs between the two groups are not statistically significant. When Bonferroni adjusted $p$ value for the number of comparisons is applied (.01) differences regarding self-depreciation are no more significant.

\section{Discussion}

The aims of the present study were to investigate social networks use among persons in emerging adulthood and to explore relationships between irrational and rational beliefs as conceptualized within RE\&CBT framework and level of problematic social networks use.

The results show that approximately $60 \%$ of participants display nonproblematic social networks use. Thus, we may presume that for the majority of the participants, the use of social networks may have beneficial effects such as those established in previous studies regarding education (Tan \& Kim, 2019), formation and maintenance of social relations (Antheunis et al., 2016; Ellison et al., 2007; Rousseau et al., 2019) and identity consolidation (e.g. Davis, 2013). However, about $40 \%$ of participants display problematic social networks use. About 30\% experience mild problems related to social networks use, while about $7 \%$ experience moderate, and $0.5 \%$ severe problematic social networks use. A comparison with other studies regarding the distribution of social networks use is constrained due to the fact that different studies use different measures and different criteria to determine problematic social networks use. A study by Musetti et al. (2021) also used the adapted version of Internet Addiction Test in a sample of 13 to 19 year old Italian adolescents. The study showed that about $14 \%$ of adolescents belong to categories of moderate or severe problematic social networks use, while the percentage of persons belonging to these categories in our sample is around 7\%. Although this difference might suggest cultural and/ or age differences, it is not justified to make such interpretations due to the small size and the unrepresentativeness of samples.

Albeit majority of the participants who display problematic social networks use in our sample belong to the category of mild problematic use, it is important to investigate which factors predispose persons for problematic social networks use. Research in this field is still relatively scarce.

In accordance with the Hypothesis 1, all types of irrational beliefs are positively related to problematic social networks use, and persons with problematic social networks use as a group have higher average levels of irrational beliefs compared to non-problematic users. This suggests that endorsement of irrational beliefs may contribute to problematic social network use. Persons who display problematic social networks use (from mild to severe) display higher 
levels of all four types of irrational beliefs. i.e., demands for other persons' correctness and other-depreciation, perfectionist demands toward oneself, demands for love and approval from others, and self-depreciation, compared to persons with non-problematic use. Results of multiple regression suggest that, when intercorrelations between beliefs are taken into account, demands for love and approval from others stand out as the single significant predictor of problematic social networks use. This is in line with previous findings on the importance of FoMO as a mechanism of excessive social networks use. We assume that irrational demands for other's love and approval may be a driving force behind FoMO. As Turkle (2011) pointed out, social networks provide numerous connections which are fast developing and superficial, thus preventing development of intimacy. Due to the lack of intimacy, persons try to find solace in even more connections, according to Turkle. So, this makes a vicious cycle and persons who irrationally demand love and approval from others may be especially prone to enter such a cycle. The results suggest that all irrational beliefs are important to be targeted in treatment and prevention of problematic social networks use, but especially demands for love and approval from others.

The results did not support the Hypothesis 2, as rational beliefs were unrelated to problematic social networks use in the present study. A previous study using SGABS also found no significant associations between rational beliefs and internet gaming disorder (Vukosavljevic-Gvozden et al., 2015). These findings are contrary to theoretical assumptions on the protective role of rational beliefs regarding emotional and behavior malfunctioning which has also received empirical support (Caserta et al., 2010). Besides, the scale of rational beliefs showed low reliability in present study. Caserta et al. (2010) point out that rational beliefs are less investigated compared to irrational beliefs and that further developments in terms of methods of their assessment are needed.

RE\&CBT interventions (educational, counseling and psychotherapeutic) have proven to be efficacious for various problems in psychosocial functioning, and to lead to positive outcomes pertaining to emotional, behavioral, cognitive and psychophysiological functioning, health, school performance, social skills, and quality of life, as shown by a review and meta-analytic study (David et al., 2018). Further, the study provided empirical evidence that the mechanism of the improvement is through the change of irrational beliefs.

Within the RE\&CBT framework, numerous prevention programs have been developed. Mostly, these programs have a general aim of supporting emotional well-being and adequate psychosocial development of the young. Among the most well-known programs are Rational-emotive Education (Knaus, 1974) and You Can Do IT! Education (Bernard, 2003), (for a review of these and other prevention programs within RE\&CBT, see Vernon \& Bernard, 2006). Changing irrational beliefs and strengthening rational thinking are among core 
principles of these programs. There is empirical evidence on the effectiveness of these programs (Knaus, 2006). Given the findings of the present study, on the relationship between irrational thinking and problematic social networks use, we may presume that prevention programs based on RE\&CBT framework may contribute to prevention of problematic social media use, although this hasn't yet been empirically investigated.

Lupu and Lupu (2013) developed and evaluated a gambling prevention program for adolescents which combined general Rational emotive education and the specific program focusing on providing information about gambling and gaming through an interactive software. The combined program outperformed Rational emotive education program regarding changes in erroneous cognitions about gambling. Following this, designing prevention programs for problematic social networks use might combine general principles of RE\&CBT approach and specific interventions regarding social networks use such as informing the young on possible negative consequences of excessive use.

In a study which also used SGABS (Vukosavljević-Gvozden et al., 2010), the same factors of irrational beliefs were obtained as in our study, suggesting stable factorial structure of the instrument. Further, the results of that study showed that, when controlling for intercorrelations between beliefs, demands for other persons' correctness and other-depreciation and perfectionist demands toward oneself are significant predictors of antisocial behavior in adolescents, with the former showing a positive and the latter a negative relationship with antisocial behavior. These results, taken together with the results of the present study, suggest that various types of irrational beliefs are generally related to problems of psychosocial functioning, but that their influence is also relatively specific depending on the type of the problem. Similarly, a study comparing personality profiles related to various forms of addictions revealed personality distinctions among different types of addictions (Zilberman et al., 2018). Contrary to this, a meta-analytic study showed that different types of irrational beliefs showed a similar pattern of relationships with various indices of psychological distress with the exception of low frustration tolerance beliefs which showed higher correlations with various psychological stress variables compared to other types of irrational beliefs. (Vîslă et al., 2016). The question of general vs. specific relationships between different types of irrational beliefs and various forms of emotional and behavioral malfunctioning requires further investigation.

The relationship between irrational beliefs and social networks use, as shown by bivariate correlations, is weak to moderate. Taken together, irrational and rational beliefs explain about $12 \%$ of variance in social networks use. This suggests that future research should aim to investigate other variables which, in interaction with irrational beliefs, or independently, contribute to social networks use. In accordance with the I-PACE model (Brand et al., 2016, 2019), irrational beliefs might be investigated in interaction with executive functions. 
Problematic social network use was assessed in the present study by adapting the Serbian version of IAT (Popović-Ćitić \& Marković, 2013). Several other studies have used the same procedure of applying the instruments constructed for other behavioral addictions to problematic social networks use. For example, Musetti et al. (2021) also used the adaptation of IAT, while Paschke et al. (2021) used an adaptation of a gaming disorder scale. There are also scales which have been specifically developed for problematic social networks use (Andreassen et al., 2017; Li et al., 2020). We decided to use the adaptation of the IAT because the instrument has been validated for use in our society (PopovićĆitić \& Marković, 2013). Further research is needed to compare psychometric properties of various instruments of problematic social networks use.

\section{Limitations and implications for future studies}

In the present study a relatively small, unrepresentative sample of emerging adults was used, thus limiting possibilities of generalization of the findings. Also, cross-sectional design of the study does not provide answers regarding the direction of influence between beliefs and problematic social networks use. Besides overcoming these limitations, future studies should focus on the relationship between problematic social networks use and other dysfunctional activities performed through the Internet, and investigate common and specific mechanisms which lead to them. This would provide information on designing prevention programs that would target various forms of Internetrelated problematic activities. Further, assessment of irrational beliefs and social networks use through experience sampling methods could provide more insights on their relationship and mechanisms of that relationship. Related to this, the development of specific measures of irrational beliefs regarding social networks use might be considered in future studies.

\section{Conclusion}

The present study suggests that irrational beliefs as conceptualized within RE\&CBT, especially demands for love and approval from others, contribute to problematic social networks use. These findings add to the empirical basis that may serve as a foundation for designing prevention and treatment programs for this form of dysfunctional Internet use.

\section{References}

Allen, K. A., Ryan, T., Gray, D. L., McInerney, D. M., \& Waters, L. (2014). Social media use and social connectedness in adolescents: The positives and the potential pitfalls. The Australian Educational and Developmental Psychologist, 31(1), 18-31. https:// doi.org/10.1017/edp.2014.2 
Andreassen, C. S., \& Pallesen, S. (2014). Social network site addiction - an overview. Current Pharmaceutical Design, 20(25), 4053-4061. https://doi.org/10.2174/13816 128113199990616

Andreassen, C. S., Pallesen, S., \& Griffiths, M. D. (2017). The relationship between addictive use of social media, narcissism, and self-esteem: Findings from a large national survey. Addictive Behaviors, 64, 287-293. https://doi.org/10.1016/j. addbeh.2016.03.006

Antheunis, M. L., Schouten, A. P., \& Krahmer, E. (2016). The role of social networking sites in early adolescents' social lives. The Journal of Early Adolescence, 36(3), 348371. https://doi.org/10.1177\%2F0272431614564060

Arnett, J. J. (2000). Emerging adulthood: A theory of development from the late teens through the twenties. American Psychologist, 55(5), 469-480. https://doi. org/10.1037/0003-066X.55.5.469

Bányai, F., Zsila, Á., Király, O., Maraz, A., Elekes, Z., Griffiths, M. D., Andreassen, C. S., $\&$ Demetrovics, Z. (2017). Problematic social media use: Results from a large-scale nationally representative adolescent sample. PloS One, 12(1), Article e0169839. https://doi.org/10.1371/journal.pone.0169839

Barker V. (2009). Older adolescents' motivations for social network site use: The influence of gender, group identity, and collective self-esteem. Cyberpsychology \& Behavior, 12(2), 209-213. https://doi.org/10.1089/cpb.2008.0228

Bates, A., Hobman, T., \& Bell, B. T. (2020). "Let me do what I please with it... Don't decide my identity for me": LGBTQ+ youth experiences of social media in narrative identity development. Journal of Adolescent Research, 35, 51-83. https://doi. org/10.1177\%2F0743558419884700

Bernard, M. (1998). Validation of the General Attitude and Belief Scale. Journal of Rational-Emotive \& Cognitive-Behavior Therapy, 16(3), 183-196. https://doi. org/10.1023/A:1024911014579

Bernard, M. E. (2003). The You Can Do It! Education mentoring program (2nd ed). Australian Scholarships Group.

Beyens, I., Frison, E., \& Eggermont, S. (2016). “I don't want to miss a thing”: Adolescents' fear of missing out and its relationship to adolescents' social needs, Facebook use, and Facebook related stress. Computers in Human Behavior, 64, 1-8. https://doi. org/10.1016/j.chb.2016.05.083

Billieux, J., Schimmenti, A., Khazaal, Y., Maurage, P., \& Heeren, A. (2015). Are we overpathologizing everyday life? A tenable blueprint for behavioral addiction research. Journal of Behavioral Addictions, 4(3), 119-123. https://doi. org/10.1556/2006.4.2015.009

Boyd, D. M., \& Ellison, N. B. (2008). Social network sites: Definition, history, and scholarship. Journal of Computer-Mediated Communication, 13(1), 210-230. http:// dx.doi.org/10.1111/j.1083-6101.2007.00393.x

Brand, M., Young, K. S., Laier, C., Wölfling, K., \& Potenza, M. N. (2016). Integrating psychological and neurobiological considerations regarding the development and maintenance of specific Internet-use disorders: An Interaction of Person-AffectCognition-Execution (I-PACE) model. Neuroscience and Biobehavioral Reviews, 71, 252-266. https://doi.org/10.1016/j.neubiorev.2016.08.033

Brand, M., Wegmann, E., Stark, R., Müller, A., Wölfling, K., Robbins, T. W., \& Potenza, M. N. (2019). The Interaction of Person-Affect-Cognition-Execution (I-PACE) model for addictive behaviors: Update, generalization to addictive behaviors beyond internet-use disorders, and specification of the process character of 
addictive behaviors. Neuroscience and Biobehavioral Reviews, 104, 1-10. https:// doi.org/10.1016/j.neubiorev.2019.06.032

Brown, B. B., \& Klute, C. (2003). Friendships, cliques, and crowds. In G. R. Adams, \& M.

D. Berzonsky (Eds.), Blackwell handbook of adolescence (pp. 330-348). Blackwell

Publishing.

Browne, C. M., Dowd, E. T., \& Freeman, A. (2010). Rational and irrational beliefs and psychopathology. In D. David, S. J. Lynn, \& A. Ellis (Eds.), Rational and irrational beliefs: Research, theory, and clinical practice (pp. 149-172). Oxford University Press.

Caserta, D. A., Dowd, E. T., David, D., \& Ellis, A. (2010). Rational and irrational beliefs in primary prevention and mental health. In D. David, S. J. Lynn, \& A. Ellis (Eds.), Rational and irrational beliefs: Research, theory, and clinical practice (pp. 173194). Oxford University Press.

Chen, I-H., Pakpour, A. H., Leung, H., Potenza, M. N., Su, J-A., Lin, C-Y., \& Griffiths, M. D. (2020). Comparing generalized and specific problematic smartphone/internet use: Longitudinal relationships between smartphone application-based addiction and social media addiction and psychological distress. Journal of Behavioral Addictions, 9(2), 410-419. https://doi.org/10.1556/2006.2020.00023

David, D., Cotet, C., Matu, S., Mogoase, C., \& Stefan, S. (2018). 50 years of rationalemotive and cognitive-behavioral therapy: A systematic review and meta-analysis. Journal of Clinical Psychology, 74(3), 304-318. https://doi.org/10.1002/jclp.22514

David, D., Freeman, A., \& DiGiuseppe, R. (2010). Rational and irrational beliefs: Implications for mechanisms of change and practice in psychotherapy. In D. David, S. J. Lynn, \& A. Ellis (Eds.), Rational and irrational beliefs: Research, theory, and clinical practice (pp. 195-217). Oxford University Press.

Davis, K. (2013). Young people's digital lives: The impact of interpersonal relationships and digital media use on adolescents' sense of identity. Computers in Human Behavior, 29(6), 2281-2293. https://doi.org/10.1016/j.chb.2013.05.022

De Cock, R., Vangeel, J., Klein, A., Minotte, P., Rosas, O., \& Meerkerk, G. J. (2014). Compulsive use of social networking sites in Belgium: Prevalence, profile, and the role of attitude toward work and school. Cyberpsychology, Behavior and Social Networking, 17(3), 166-171. https://doi.org/10.1089/cyber.2013.0029

DiGiuseppe, R. A., Doyle, K. A., Dryden, W., \& Backx, W. (2014). A practitioner's guide to rational emotive behavior therapy (3rd ed.). Oxford University Press.

DiGiuseppe, R., Leaf, R., Exner, T., \& Robin, M. (1988, September). The development of a measure of irrational/rational thinking [Paper presentation]. World Congress of Behavior Therapy, Edinburgh, Scotland.

Ellis, A. (1994). Reason and emotion in psychotherapy (Rev. ed.). Birch Lane.

Ellis, A., \& Dryden, W. (1997). The practice of rational emotive behavior therapy (2nd ed.). Springer Publishing Co.

Ellison, N. B., Steinfield, C., \& Lampe, C. (2007). The benefits of Facebook "friends:" Social capital and college students' use of online social network sites. Journal of Computer-Mediated Communication, 12(4), 1143-1168. https://doi.org/10.1111/ j.1083-6101.2007.00367.x

Gámez-Guadix, M. (2014). Depressive symptoms and problematic internet use among adolescents: Analysis of the longitudinal relationships from the cognitive-behavioral model. Cyberpsychology, Behavior and Social Networking, 17(11), 714-719. https:// doi.org/10.1089/cyber.2014.0226 
Grant, J. E., Potenza, M. N., Weinstein, A., \& Gorelick, D. A. (2010). Introduction to behavioral addictions. The American Journal of Drug and Alcohol Abuse, 36(5), 233-241. https://doi.org/10.3109/00952990.2010.491884

Griffiths, M. D., \& Szabo, A. (2014). Is excessive online usage a function of medium or activity? An empirical pilot study. Journal of Behavioral Addictions, 3(1), 74-77. https://doi.org/10.1556/JBA.2.2013.016

Hormes, J. M., Kearns, B., \& Timko, C. A. (2014). Craving Facebook? Behavioral addiction to online social networking and its association with emotion regulation deficits. Addiction, 109(12), 2079-2088. https://doi.org/10.1111/add.12713

Kalpidou, M., Costin, D., \& Morris, J. (2011). The relationship between Facebook and the well-being of undergraduate college students. Cyberpsychology, Behavior and Social Networking, 14(4), 183-189. https://doi.org/10.1089/cyber.2010.0061

Kirschner, P. A., \& Karpinski, A. C. (2010). Facebook ${ }^{\circledR}$ and academic performance. Computers in Human Behavior, 26(6), 1237-1245. https://doi.org/10.1016/j. chb.2010.03.024

Knaus, W. (1974). Rational-emotive education: A manual for elementary school teachers. Institute for Rational Living.

Knaus, W. J. (2006). Frustration tolerance training for children. In A. Ellis, \& M. E. Bernard (Eds.), Rational emotive behavioral approaches to childhood disorders: Theory, practice and research (pp. 133-155). Springer.

Li, J-B., Wu, A. M. S., Feng, L-F., Deng, Y., Li, J-H., Chen, Y-X., Mai, J-C., Mo, P. K. H., \& Lau, J. T. F. (2020). Classification of probable online social networking addiction: A latent profile analysis from a large-scale survey among Chinese adolescents. Journal of Behavioral Addictions, 9(3), 698-708. https://doi.org/10.1556/2006.2020.00047

Lupu, I. R., \& Lupu, V. (2013). Gambling prevention program for teenagers. Journal of Cognitive and Behavioral Psychotherapies, 13(2a), 575-584.

Lyvers, M, Narayanan, S. S., \& Thorberg, F. A. (2019). Disordered social media use and risky drinking in young adults: Differential associations with addiction-linked traits. Australian Journal of Psychology, 71(3), 223-231. https://doi.org/10.1111/ajpy.12236

Marić, Z. (2002). Kognitivni činioci emocije i emocionalnog poremećaja iz ugla REBT [Cognitive factors of emotion and emotional disorder from the REBT point of view] [Unpublished master's thesis]. Univerzitet u Beogradu - Filozofski fakultet.

Marić, Z. (2003). Uloga disfunkcionalnih stavova u depresivnom raspoloženju i provera medijacionog efekta "vrelih" evaluativnih kognicija [The role of dysfunctional attitudes in depressive mood and the mediation effect of "hot" evaluative cognitions]. Psihologija, 36(1-2), 101-115. https://doi.org/10.2298/PSI0301101M

Müller, K. W., Dreier, M., Beutel, M. E., Duven, E., Giralt, S., \& Wölfling, K. (2016). A hidden type of internet addiction? Intense and addictive use of social networking sites in adolescents. Computers in Human Behavior, 55(Part A), 172-177. https://doi. org/10.1016/j.chb.2015.09.007

Musetti, A., Starcevic, V., Boursier, V., Corsano, P., Billieux, J., \& Schimmenti, A. (2021). Childhood emotional abuse and problematic social networking sites use in a sample of Italian adolescents: The mediating role of deficiencies in self-other differentiation and uncertain reflective functioning. Journal of Clinical Psychology, 77(7), 16661684. https://doi.org/10.1002/jclp.23138

Oberst, U., Wegmann, E., Stodt, B., Brand, M., \& Chamarro, A. (2017). Negative consequences from heavy social networking in adolescents: The mediating role of fear of missing out. Journal of Adolescence, 55, 51-60. https://doi.org/10.1016/j. adolescence.2016.12.008 
Oltean, H. R., \& David, D. O. (2018). A meta-analysis of the relationship between rational beliefs and psychological distress. Journal of Clinical Psychology, 74(6), 883-895. https://doi.org/10.1002/jclp.22562

Orben, A. (2020). Teenagers, screens and social media: A narrative review of reviews and key studies. Social Psychiatry and Psychiatric Epidemiology, 55(4), 407-414. https://doi.org/10.1007/s00127-019-01825-4

Paschke, K., Austermann, M. I., \& Thomasius, R. (2021). ICD-11-based assessment of social media use disorder in adolescents: Development and validation of the Social Media Use Disorder Scale for Adolescents. Frontiers in Psychiatry, 12, Article 661483. https://doi.org/10.3389/fpsyt.2021.661483

Petry, N. M., Zajac, K., \& Ginley, M. K. (2018). Behavioral addictions as mental disorders: To be or not to be? Annual Review of Clinical Psychology, 14, 399-423. https://doi. org/10.1146/annurev-clinpsy-032816-045120

Piteo, E. M., \& Ward, K. (2020). Review: Social networking sites and associations with depressive and anxiety symptoms in children and adolescents - a systematic review. Child and Adolescent Mental Health, 25(4), 201-216. https://oi.org/10.1111/ camh.12373

Pontes, H. M. (2017). Investigating the differential effects of social networking site addiction and Internet gaming disorder on psychological health. Journal of Behavioral Addictions, 6(4), 601-610. https://doi.org/10.1556/2006.6.2017.075

Pontes, H. M., Taylor, M., \& Stavropoulos, V. (2018). Beyond "Facebook addiction": The role of cognitive-related factors and psychiatric distress in social networking site addiction. Cyberpsychology, Behavior and Social Networking, 21(4), 240-247. https://doi.org/10.1089/cyber.2017.'0609

Popović-Ćitić, B., \& Marković, M. (2013). Faktorska struktura testa internet-zavisnosti kod učenika starijih razreda osnovnih škola [Factorial structure of internet addiction test for students in senior grades of elementary school]. Specijalna edukacija $i$ rehabilitacija, 12(2), 179-200. https://doi.org/10.5937/specedreh12-3595

Przybylski, A. K., Murayama, K., DeHaan, C. R., \& Gladwell, V. (2013). Motivational, emotional, and behavioral correlates of fear of missing out. Computers in Human Behavior, 29(4), 1841-1848. https://doi.org/10.1016/j.chb.2013.02.014

Rousseau, A., Frison, E., \& Eggermont, S. (2019). The reciprocal relations between Facebook relationship maintenance behaviors and adolescents' closeness to friends. Journal of Adolescence, 76, 173-184. https://doi.org/10.1016/j.adolescence.2019.09.001

Sampasa-Kanyinga, H., \& Lewis, R. F. (2015). Frequent use of social networking sites is associated with poor psychological functioning among children and adolescents. Cyberpsychology, Behavior and Social Networking, 18(7), 380-385. https://doi. org/10.1089/cyber.2015.0055

Shah, J., Das, P., Muthiah, N., \& Milanaik, R. (2019). New age technology and social media: Adolescent psychosocial implications and the need for protective measures. Current Opinion in Pediatrics, 31(1), 148-156. https://doi.org/10.1097/ MOP.0000000000000714

Starcevic, V., \& Aboujaoude, E. (2017). Internet addiction: Reappraisal of an increasingly inadequate concept. CNS Spectrums, 22(1), 7-13. https://doi.org/10.1017/ S1092852915000863

Sussman, S., \& Arnett, J. J. (2014). Emerging adulthood: Developmental period facilitative of the addictions. Evaluation \& The Health Professions, 37(2), 147-155. https://doi. org/10.1177/0163278714521812 
Szentagotai, A., \& Jones, J. (2010). The behavioral consequences of irrational beliefs. In D. David, S. J. Lynn, \& A. Ellis (Eds.), Rational and irrational beliefs: Research, theory, and clinical practice (pp. 75-97). Oxford University Press.

Tan, L., \& Kim, B. (2019). Adolescents' agentic work on developing personal pedagogies on social media. Literacy, 53(4), 196-205. https://doi.org/10.1111/lit.12180

Turkle, S. (2011). Alone together: Why we expect more from technology and less from each other. Basic Books.

Verduyn, P., Ybarra, O., Résibois, M., Jonides, J., \& Kross, E. (2017). Do social network sites enhance or undermine subjective well-being? A critical review. Social Issues and Policy Review, 11(1), 274-302. https://doi.org/10.1111/sipr.12033

Vernon A., \& Bernard M. E. (2006). Applications of REBT in schools: Prevention, promotion, intervention. In A. Ellis, \& M. E. Bernard (Eds.), Rational emotive behavioral approaches to childhood disorders: Theory, practice and research (pp. 415-460). Springer.

Vîslă, A., Flückiger, C., grosse Holtforth, M., \& David, D. (2016). Irrational beliefs and psychological distress: A meta-analysis. Psychotherapy and Psychosomatics, 85(1), 8-15. https://doi.org/10.1159/000441231

Vukosavljevic-Gvozden, T., Filipovic, S., \& Opacic, G. (2015). The mediating role of symptoms of psychopathology between irrational beliefs and internet gaming addiction. Journal of Rational-Emotive and Cognitive-Behavior Therapy, 33(4), 387-405. https://doi.org/10.1007/s10942-015-0218-7

Vukosavljević-Gvozden, T., Opačić, G., \& Marić, Z. (2010). Iracionalne evaluacije i antisocijalno ponašanje adolescenata [Irrational evaluations and antisocial behavior of adolescents]. Zbornik Instituta za pedagoška istraživanja, 42(2), 263-276. https:// doi.org/10.2298/ZIPI1002263V

Wegmann, E., Müller, S. M., Turel, O., \& Brand, M. (2020). Interactions of impulsivity, general executive functions, and specific inhibitory control explain symptoms of social-networks-use disorder: An experimental study. Scientific Reports, 10(1), Article 3866. https://doi.org/10.1038/s41598-020-60819-4

Wegmann, E., Oberst, U., Stodt, B., \& Brand, M. (2017). Online-specific fear of missing out and Internet-use expectancies contribute to symptoms of Internet-communication disorder. Addictive Behaviors Reports, 5, 33-42. https://doi.org/10.1016/j. abrep.2017.04.001

Wegmann, E., Ostendorf, S., \& Brand, M. (2018). Is it beneficial to use Internetcommunication for escaping from boredom? Boredom proneness interacts with cueinduced craving and avoidance expectancies in explaining symptoms of Internetcommunication disorder. PloS One, 13(4), Article e0195742. https://doi.org/10.1371/ journal.pone.0195742

Young, K. S. (1997). Internet addiction: The emergence of a new clinical disorder. CyberPsychology \& Behavior, 1(3), 237-244. https://doi.org/10.1089/cpb.1998.1.237

Young, K. S. (2011). Clinical assessment of internet-addicted clients. In K. S. Young, \& C. Abreu (Eds.), Internet addiction: A handbook and guide to evaluation and treatment (pp. 19-34). John Wiley \& Sons, Inc.

Zilberman, N., Yadid, G., Efrati, Y., Neumark, Y., \& Rassovsky, Y. (2018). Personality profiles of substance and behavioral addictions. Addictive Behaviors, 82, 174-181. https://doi.org/10.1016/j.addbeh.2018.03.007 


\title{
Korišćenje društvenih mreža među mladima: Uloga iracionalnih uverenja
}

\author{
Irena B. Stojkovića, Tatjana D. Vukosavljević-Gvozden ${ }^{\mathrm{b}}$ \\ ${ }^{a}$ Univerzitet u Beogradu - Fakultet za specijalnu edukaciju i rehabilitaciju, Beograd, Srbija \\ ${ }^{b}$ Univerzitet u Beogradu-Filozofski fakultet, Beograd, Srbija
}

Uvod: Korišćenje društvenih mreža na internetu je postalo široko raprostranjeno među mladima. Mada ono može imati povoljne efekte, ustanovljeno je da neke osobe razvijaju problematično ili preterano korišćenje društvenih mreža što može imati negativno dejstvo na njihovo psihosocijalno funkcionisanje. Cilj: Cilj ove studije bio je da se istraži korišćenje društvenih mreža među mladima i da se ispita da li iracionalna i racionalna uverenja shvaćena sa stanovišta racionalno-emocionalne i kognitivno-bihevioralne terapije (RE i KBT) predviđaju problematično korišćenje društvenih mreža. U skladu sa RE i KBT pristupom, pretpostavili smo da su iracionalna uverenja u pozitivnoj, a racionalna uverenja u negativnoj korelaciji sa problematičnim korišćenjem društvenih mreža. Metode: Uzorak je obuhvatio 210 mladih osoba (starosti od 18 do 26 godina, $A S$ $=21.08, S D=2.02$ ) od kojih je $59.0 \%$ ženskog pola. Srpska verzija Skale opštih stavova i uverenja je korišćena za procenu iracionalnih i racionalnih uverenja. Srpska verzija Testa zavisnosti od interneta je prilagođena za procenu problematičnog korišćenja društvenih mreža. Rezultati: U skladu sa pretpostavkom, iracionalna uverenja su u pozitivnoj korelaciji sa problematičnim korišćenjem društvenih mreža. Kada su kontrolisane interkorelacije između uverenja, zahtevi za ljubavlju i odobravanjem od strane drugih su se izdvojili kao jedini značajan prediktor problematičnog korišćenja društvenih mreža. Racionalna uverenja nisu povezana sa problematičnim korišćenjem društvenih mreža, suprotno pretpostavci. Zaključak: Rezultati ukazuju da RE i KBT pristup, koji se pokazao kao delotvoran u prevenciji različitih oblika psihosocijalnih problema, može predstavljati okvir za pružanje podrške mladima da koriste socijalne mreže na konstruktivan način.

Ključne reči: problematično korišćenje društvenih mreža, iracionalna uverenja, racionalna uverenja, racionalno-emocionalni i kognitivno-bihevioralni pristup, mladi

PRIMLJENO: 17.06.2021.

REVIDIRANO: 15.09.2021.

PRIHVAĆENO: 20.09.2021.

Specijalna edukacija i rehabilitacija, 20(4), 219-238, 2021 